\title{
BUDAYA BERMUKIM MASYARAKAT JAWA
}

\author{
Arya Ronald \\ Jl. Dr. Soetomo 74, Yogyakarta \\ Email : arya211143@yahoo.co.id
}

\begin{abstract}
ABSTRAK
Atas ridhlo Allah SWT, dengan segala kerendahan hati kami ingin menghadirkan sebuah karya tulis, yang barangkali dapat menggugah kesadaran para pembaca terhormat, bahwa kita mempunyai peninggalan budaya nenek moyang yang tidak ternilai tingginya di sekitar kehidupan kita. Penulisan sebelum ini telah banyak mengungkap berbagai nilai, yang melekat pada karya budaya mereka, yang di dalamnya tersirat idealisme dan perilaku mereka pada waktu itu. Setelah itu, timbul keinginan untuk melakukan penelitian tentang perkembangan rumah masyarakat Jawa yang tinggal di kota pada periode akhir abad ke 20 ini, sebab sepintas lalu terlihat gejala bahwa masyarakat Jawa telah banyak meninggalkan berbagai kaidah yang berhubungan dengan pembangunan rumahnya. Jadi tulisan ini bertujuan menjelaskan bahwa sebuah karya arsitektur pada dasarnya adalah sebuah bahasa, yang mengungkapkan pesan budaya kepada umum.
\end{abstract}

\section{Kata Kunci: budaya, bahasa, arsitektur}

\section{PENDAHULUAN}

Bangsa Indonesia termasuk dalam rumpun bangsa yang tinggal di kawasan Asia Tenggara, banyak dipengaruhi oleh suku bangsa Cina, India dan kepulauan Pasifik Selatan. Mereka membawa pola kehidupan budaya masing-masing, sambil melakukan penyebaran ke berbagai pulau dan kepulauan di Indonesia, seperti dari daratan Asia Tenggara yang membawa muatan budaya Cina dan India. Menjalar masuk melalui jazirah Melayu, kemudian meneruskan sebarannya ke beberapa pulau seperti Sumatera dan Kalimantan, berlanjut ke Sulawesi dan Jawa. Sebaran rumpun bangsa ini berlanjut ke arah kepulauan Nusa Tenggara bagian Barat. Sebaran ini membawa serta kehidupan budayanya sendiri. Ketika sebaran itu telah bercampur, maka mulailah berkembang menjadi suku bangsa baru, yang tinggal di wilayah yang berbeda-beda kemudian membentuk warna budaya baru pula.

Suku Jawa dalam hal kehidupan budayanya - menurut penuturan berbagai acuan (Geertz,C.,1960) menunjukkan bahwa pada jaman yang hampir bersamaan dengan suku bangsa lain di Indonesia, termasuk suku bangsa yang telah mapan. Kemapanan ini dapat ditemukan dari beberapa realita, yang dapat diperiksa dari bukti-bukti yang telah ditemukan. Bukti-bukti itu antara lain dari kemapanan berbahasa, pengetahuan yang ditandai oleh ungkapan bernilai filsafat, aneka usaha untuk dijadikan mata-pencahariannya selain bercocok-tanam juga berdagang dan berolah jasa, teknologi dalam mewujudkan rumah sebagai tempat tinggalnya dan aneka kesenian - mulai dari seni sastra, musik, pentas, aneka rupa dan seni bangunan (Wessing.R.,1978). Dari berbagai ungkapan karya budaya mereka yang dapat dibaca dari karya sastranya, tampak sekali bahwa mereka telah hidup dan berkembang cukup pesat tidak hanya dalam karyanya saja, tetapi juga dalam berperi-laku dan bahkan juga dalam mengembangkan aneka gagasan. (Hardjowirogo, 1984)

\section{PEMBAHASAN}

Kebudayaan Jawa sebagai sebuah wawasan menunjukkan bahwa masyarakat Jawa memiliki satu bentuk pandangan hidup yang cukup matang, hal itu ditandai dengan aneka kepercayaan yang mereka anut, aneka pengetahuan atau keilmuan yang diserap, kehidupan penuh dengan etika dan nilai estetika yang berpola sangat mendasar. Salah satu bentuk pandangan hidup yang dapat diterangkan secara panjang lebar 
adalah faham kejawen, yang hidup di antara kepercayaan dan agama yang berkembang saat itu. Sebagai sebuah faham, maka faham inipun mempunyai bentuk ajaran yang cukup mantap, antara lain dalam filsafat kosmologi Jawa, yang mampu mengawali perkembangan teologi di kemudian hari (Hadiwijono, H., 1967). Pada masa-masa kejayaannya, faham ini berkembang dan telah begitu mengakar dalam sebagian besar hidup berbudaya mereka, sehingga sampai saat inipun faham itu masih banyak dijumpai tetap berada dalam kehidupan masyarakat Jawa. Kalau faham-faham ini cenderung muncul dalam ungkapan yang dipergunakan dalam rangka berkomunikasi dengan pihak lain atau berbahasa, salah satu bentuk bahasa lain yaitu bahasa non-verbal, terungkap dalam karya mereka yaitu rumah tinggal - sebagai karya arsitektur mereka (Herusatoto, B., 1983).

\section{ARSITEKTUR JAWA}

Arsitektur sebagai satu bentuk hasil budaya masyarakat Jawa, mengandung beberapa prinsip yaitu meliputi ungkapan fungsional, estetika dan susunan detil konstruksi. Dalam kenyataan yang dapat diketemukan dalam artefak yang mereka tinggalkan dari sejak jaman lalu, terlihat bahwa baik ungkapan fungsional, estetika maupun konstruksi erat hubungannya dengan pola pikir dan perilaku mereka, banyak mengacu kepada faham kejawen sebagai landasan filsafat kosmologinya. Seperti dapat dilihat pada bangunan rumah tinggal jabatan Bupati Juru Kunci Puralaya di Imogiri, yang dalam gaya, sifat maupun kegunaan bangunannya memperlihatkan peran, status dan kedudukannya sebagai pelayan/petugas (abdi dalem) keraton, mempunyai kewajiban menerima Sultan bersama keluarganya, sebelum berjalan terus melanjutkan perjalanan berziarah ke makam raja-raja di bukit Imogiri dan selain itu juga mengayomi masyarakat yang tinggal di sekitarnya.

Semisal dalam sebuah ungkapan Jawa 'manunggaling kawula lan gusti', memberikan indikasi cukup kuat bahwa eksistensi seseorang itu (dalam gambar 1 ditunjukkan contoh rumah jabatan Juru Kunci makam rajaraja di Imogiri, Bantul, DIY) berada menyatu dengan kekuatan yang lebih tinggi dan lebih besar yaitu Kasultanan Ngayogyakarta
Hadiningrat, sehingga terbentuklah keseimbangan yang bernilai universal (Mulder,J.A.N., 1975). Ungkapan semacam itu pada awalnya merupakan suatu ajaran atau nasehat (pitutur), namun ternyata dapat diterjemahkan/ ditransformasikan ke dalam aneka bentukan baik yang tampak (tengible) maupun yang tidak tampak (intengible). Salah satu wajah/ bentuk yang tampak adalah perwujudan arsitektur rumah Jawa, terdiri dari beberapa bangunan di dalamnya yaitu Topengan, Pendhapa, Pringgitan, Dalem Ageng, Andong Sekar, juga Gedhong Abang, Gedhong Kanthil, Pawetan, Patehan, Paseban, Gedhong Gangsa dan Regol. Kalau ungkapan itu sebuah ajaran, maka demikian pula halnya dengan arsitektur rumah Jawa - dengan penamaan dan pembedaan fungsi tiap bangunan, dapat kiranya merefleksikan keberadaannya menjadi suatu bentuk ajaran pula. Ajaran itu khususnya ditujukan kepada penghuninya dan secara umum kepada pihak lain yang berhubungan sosial dan budaya dengan penghuni rumah.

Arsitektur sebagai sebuah karya budaya dapat menempatkan diri menjadi salah satu bagian dari unsur kebudayaan Jawa (Koentjaraningrat, 1984) - terdiri dari unsur bahasa, sistem kepercayaan, sistem sosial, sistem ekonomi, sistem pengetahuan, teknologi dan kesenian.

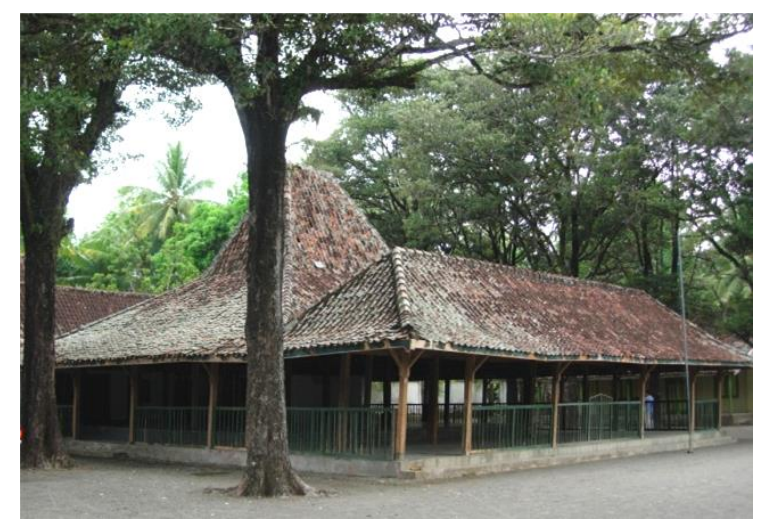

Gambar 1. Dalem Bupati Juru Kunci

Puralaya,Imogiri Sumber: Dokumen Penulis

Bilamana diarahkan pada kedudukan rumah Jawa dalam kajian kebendaan, maka objek itu dekat dengan unsur-unsur teknologi dan kesenian (seni bangunan), namun seperti telah disinggung sebelumnya bahwa ternyata unsur-unsur kebudayaan Jawa yang lain juga 
melekat pada rumah itu, seperti halnya faham kosmologi yang kadang-kala meningkat menjadi sebuah kepercayaan, bahasa arsitektur, status sosial penghuni, derajat ekonomi penghuni rumah dan kapasitas seseorang dalam pengembangan ilmu dan teknologi di lingkungan sekitarnya ( Minai, A.T.,1984). Dalam hal demikian ini keberadaan arsitektur rumah Jawa dapat dijadikan acuan cukup berbobot untuk mengenal manusia dan masyarakat Jawa seutuhnya - baik dalam hubungannya dengan peran, kekuasaan maupun kekuatannya, yang terjadi dalam lingkup kehidupan budaya Jawa.

Pembangunan rumah tinggal di mana dan kapanpun merupakan masalah hidup utama, sebab rumah merupakan salah satu dari sekian tuntutan kebutuhan utama manusia. Masalah kebutuhan utama hidup manusia yang difahami oleh masyarakat Indonesia pada umumnya dan Jawa khususnya adalah pangan, sandang dan papan; yang terakhir yaitu papan diterima secara sempit sebagai tempat tinggal atau rumah, meskipun secara lebih luas lagi dapat berarti bahwa semua tempat yang akan dipergunakan untuk tinggal manusia - baik dalam waktu singkat maupun lama - adalah papan yang dipungut dari istilah Jawa papan dan mapan (mantab atau stabil). Dengan pemahaman ini dapat ditafsirkan sementara bahwa mereka selalu berusaha untuk hidup dan menetap lebih mantab dalam kurun waktu lama, sehingga diungkapkan dengan istilah kerasan atau dapat bertahan cukup lama. Agar supaya kehidupan menjadi stabil, maka hubungan satu dengan lain anggota masyarakat harus sampai kepada tingkatan akrab, saling memperhatikan, bahkan juga saling tolong-menolong atau gotong-royong seperti terlihat pada upaya mereka membangun rumah, yang pada dasarnya mendapat bantuan dari tenaga para tetangga di sekitarnya.

Lagi, ternyata bahwa pembangunan rumah tinggal itu sendiri saat ini tidak lagi sama dengan pada masa yang lalu, bahwa rumah itu dikerjakan oleh para tetangga di sekitarnya - kalau di pedesaan, sedang kalau di perkotaan kebanyakan sudah diserahkan begitu saja kepada pemborong bangunan secara profesional. Bagi generasi lampau pembangunan dipandang sebagai proses mendirikan rumah yang berlangsung dalam jangka waktu yang cukup panjang, mulai dari perencanaan sampai dengan mewujudkan bangunan itu; sedangkan saat ini pembangunan dapat dianggap suatu kegiatan yang tidak perlu dilakukan sendiri oleh calon penghuninya. Dengan demikian, masalah berkaitan dengan pembangunan rumah telah bergeser dari tanggung-jawab keluarga menjadi tanggungjawab umum atau bahkan pihak pemerintah.

Bagi manusia Jawa rumah adalah bagian dari kehidupan budaya, yang pada masa lalu merupakan bayangan cermin dari kepribadian manusianya, sebagian dilihat dari penampakan luarnya - namun dengan mempelajari bagian-bagian dari rumah dapatlah segera diketahui nilai kepribadian manusia yang melatar-belakangi kehadiran rumah dalam lingkungan permukiman itu. Dari kedua sisi itu yaitu kebudayaan dan kepribadian, kemudian dijabarkan ke dalam unsur-unsurnya, artinya bilamana dicari rumusan berkaitan dengan kebutuhan manusia akan rumah tinggal yang timbul dari persilangan itu, dapatlah segera difahami bahwa ternyata keberadaan rumah bagi tiap individu yang bergabung dalam sebuah rumah tangga mengandung banyak sekali pertimbangan (Mulder, N., 1973). Unsur-unsur kebudayaan itu adalah: bahasa, organisasi sosial, sistem pengetahuan, peralatan hidup dan teknologi, mata-pencaharian hidup, atau kehidupan beragama, religi atau berkepercayaan dan kesenian (Koentjaraningrat, 1980). Unsur kepribadian itu adalah: pengalaman melakukan hubungan antar manusia, sistem nilai, pola pikir, sikap hidup, perilaku hidup dan kaidah hidup. (Soekanto, S. dan Soleman, B.T., 1983) Bilamana kedua unsur itu dipersilangkan, seharusnya muncul sebuah karya dari hasil berbudi daya, sekaligus karya itu memancarkan sinar kepribadian pemilik atau penghuninya.

\section{PERUBAHAN BUDAYA BERMUKIM}

Beberapa segi yang mempengaruhi proses pembangunan rumah tinggal - baik pada masa yang lalu, maupun sekarang perlu difahami perubahan pengaruhnya, mengingat bahwa dengan aspek yang sama ternyata menghasilkan eksistensi rumah tinggal yang berbeda. Dengan memahami proses pem-bangunan rumah tinggal dan kaitannya dengan kehidupan budaya dan 
perkem-bangan bentuk kepribadiannya dapat di-bayangkan bahwa pembangunan rumah seharusnya dari waktu ke waktu akan selalu mengalami perubahan, baik itu dipengaruhi oleh tuntutan dari dalam maupun tantangan dari luar. Kalau yang mempengaruhi proses itu masih dalam lingkup kebudayaan dan kepribadian saja, maka tuntutan dari luar dan dari dalam telah cukup untuk melakukan perubahan dalam proses pembangunan rumah. (Mulder,N.,1973). Yang perlu dikhawatirkan adalah bilamana pembangunan itu tidak lagi memiliki landasan kebudayaan, apalagi kalau dilakukan dengan mengabaikan kepribadian yang seharusnya melekat pada diri orang yang berkepentingan membuat rumahnya sendiri.

Dengan demikian telah menjadi satu kenyataan, bahwa terdapat pergeseran pola mulai dari tanggung-jawab keluarga menjadi tanggung-jawab umum. Salah satu aspek dari masing-masing sisi yang dapat dipastikan mempengaruhi proses ini adalah sistem pengetahuan dari sisi kebudayaan dan pola pikir dari sisi kepribadian, telah cukup untuk merubah proses itu. Secara umum, keduanya telah bertolak dari alam kehidupan tradisional yang statik menurut pendapat orang yang anti tradisi menuju kenyataan global yang dinamik.

Tulisan ini akan berusaha membuat sistematika perubahan yang terjadi pada tiap aspek bilamana mungkin, sekaligus juga membuat sistematika tentang hal-hal yang akan berpengaruh pada pembangunan rumah sejak masa lalu dan sekarang. Sistem pengetahuan yang dipergunakan seharusnya mengacu pada sistem pohon ilmu pengetahuan, sedang pola pikir hendaknya mengacu pada pola pendekatan kefilsafatan.

Globalisasi sebagai kebudayaan mengandung beberapa ujud budaya antara lain adalah pola-pikir global yang di dalamnya terdapat unsur karakteristik yang relevan dengan pertimbangan berlingkup internasional, yang juga berkaitan dengan pengertian standardisasi, desentralisasi dan interaksi (Afiff,F.,1994). Pola pikir berarah pada produk standard telah beranggapan bahwa kehidupan budaya manusia mempunyai nilai rata-rata, sekalipun nilai rata-rata ini untuk budaya bangsa satu dengan lainnya tidak sama. Pada masa perkembangan budaya akhir-akhir ini telah diupayakan untuk disamaratakan artinya bahwa nilai rata-rata itu hendaknya sama untuk semua bangsa di dunia ini. Dengan nilai rata-rata yang sama ini, maka semua tuntutan kebutuhan dan tantangan hidup manusia akan berada pada garis rata-rata. Kalau tuntutan dan tantangan itu telah sama, berarti pelayanan untuk memenuhi tuntutan dan persiapan untuk dapat menghadapi tantangan dapat disediakan dengan format yang sama pula. Timbul pertanyaan, apakah dengan pola pikir tentang standard ini nantinya akan memberikan kemudahan atau justru akan membuat kehidupan manusia makin terbelenggu?

Pola berpikir desentralisasi, timbul anggapan bahwa hidup manusia tumbuh dan berkembang bersama-sama dengan perkembangan bentuk kegiatan sehari-hari, bersama-sama dengan orang lain dalam suatu kelompok tertentu. Kegiatan itu sendiri akan terbentuk dengan ciri-ciri khasnya sendiri, sehingga kelompok satu dengan lainnya mempunyai potensi dan kondisi tertentu yang dapat menghasilkan perbuatan dan karya budaya (artefak) yang khas pula. Mengingat bahwa nilai rata-rata hidup semua orang tetap sama, namun derajat profesionalitas kelompok satu dengan lainnya dapat berbeda, maka produk yang dihasilkan oleh kelompok tertentu akan lebih baik dari kelompok yang lain - sekalipun hasil itu semua dapat dimanfaatkan oleh semua orang. Dari pola pikir demikian, telah menunjukkan bahwa kelompok masyarakat atau bangsa tertentu dapat menjadi sumber inspirasi, inisiatif dan kreasi bagi pihak lain dan pihak lain tentu akan memanfaatkannya semaksimal mungkin. Timbul pertanyaan, dapatkah kererataan seperti itu memunculkan sistem desentralisasi yang berkembang sehat, seimbang dan serasi?

- Pola pikir yang berkaitan dengan interaksi, menganggap bahwa manusia akan dapat hidup dengan baik manakala tidak membatasi dirinya dalam lingkungan hidup yang sempit dengan radius yang sangat terbatas. Dengan perkataan lain, mau membuka dirinya dengan melakukan interaksi secara meluas ke segala penjuru dengan kelompok masyarakat atau bangsa lain. Interaksi ini membuka wawasan seseorang agar mengenal dengan baik nilai rata-rata yang sama untuk semua orang, juga memahami potensi dan kondisi pihak lain untuk dapat mengukur peran, 
status dan kedudukan dalam kehidupan manusia di dunia ini. Interaksi ini nantinya akan menumbuh-kembangkan kesadaran dirinya untuk menerima standardisasi dan desentralisasi yang baru, yang sebelumnya tidak pernah dikenalnya sama sekali, yang akhirnya akan diterima sebagai suatu kenyataan hidup. Dari jabaran tentang ketiga bentuk pola pikir global, kemudian timbullah pertanyaan: apakah pola pikir semacam ini merupakan barang baru bagi masyarakat Indonesia pada umumnya dan masyarakat di daerah khususnya atau telah ada sejak beberapa waktu yang lalu? Pertanyaan ini perlu memperoleh jawaban mengingat permasalahan global telah dekat sekali di depan telinga semua orang di negara ini terutama mereka yang telah akrab dengan kehidupan perkotaan.

- Bertitik-tolak kepada pemahaman tentang global secara terbatas, sementara istilah Jawa sudah mendunia, diketahui oleh masyarakat dunia, telah dipakai oleh masyarakat dunia, maka timbul pertanyaan bukankah pengertian Jawa dan budayanya merupakan budaya yang global pula. Hal ini dapat dikemukakan di sini mengingat bahwa keberadaan manusia Jawa boleh dikatakan mendunia, dengan pengertian bahwa tiap orang Jawa di manapun dapat melakukan kontak dan hubungan sosial, budaya dan ekonomi dengan siapapun di dunia, sehingga dia dapat mempengaruhi dan dapat pula menerima pengaruh dari siapapun. Kalaulah kerataan dalam globalisasi ditandai dengan standardisasi, desentralisasi dan interaksi, maka tiap orang Jawa itu bertolak dari kepentingan dan kebutuhannya sendiri pasti akan membentuk format kehidupan berdasarkan modal budaya yang dibawanya. Dengan begitu, tanpa kampanye besar-besaran tentang globalisasi, keberadaan budaya Jawa itu sendiri telah membentuk atmosfer kehidupan global.

Globalisasi sebagai satu pengaruh, pada umumnya menyentuh kehidupan pada beberapa segi, sebagai berikut:

- pemikiran global yang melepaskan diri dari ikatan spesifikasi lokal maupun nasional dan juga mengarah ke multi-nasional dan untuk selanjutnya ke internasional; spesifikasi yang juga berkembang pada saat ini terdorong oleh kehendak eksklusif lain dengan lingkungan masyarakat di sekitarnya; kecenderungan ini diciptakan jelas untuk memperoleh perlindungan (proteksi) dengan menampilkan identitas yang melekat dengan dirinya dan lingkungan atau kerabat terdekatnya; pemikiran global itu pada dasarnya mempunyai kecenderungan besar tumbuh berarah sebaliknya, yaitu mengurangi sebanyak mungkin ciri-ciri eksklusif, bergeser menuju ke arah kepentingan ratarata, sehingga secara sosio-psikologis timbul kelonggaran atau toleransi perasaan yang cukup besar

- sikap global yang beralih dari tradisional statik (vernakular) menuju ke dinamikproduktif yang akan membuka diri untuk bermitra kerja dengan pihak di luar lingkungan kehidupan tradisional; sikap vernakular timbul karena segala bentuk kinerja yang dirasakan telah mencapai titik mapan; membuat orang terlena untuk tidak mengembangkan lagi padahal keadaan di sekitarnya akan tumbuh dan juga berkembang terus; kehidupan budaya itu pada dasarnya sepanjang masa akan selalu mengalami pengembangan, akibat dari besarnya pengaruh luar yang dapat masuk dan merasuki pola pikir masyarakat, yang berarti pengaruh ini harus ditanggapi dengan sikap dinamik yang produktif untuk menjaga diri agar tidak tertinggal oleh arus kemajuan yang terjadi di lingkungan sekitarnya

- perilaku global yang melakukan interaksi kerja dengan cara alih orientasi dari soal memenuhi kebutuhan dan kepentingan lingkungan yang terbatas dan terlalu berpihak pada alur historik yang pernah ada, menuju kepada perluasan batas yang berpihak pada kepentingan dunia luas atau dunia internasional; dalam lingkup perilaku ini di dalamnya terdapat unsur tutur-kata (bahasa, sistem, metoda komunikasi), tingkah laku (sepak-terjang yang efisien/ berdaya-guna dan efektif / berhasil guna), tindak-tanduk (etika profesional yang universal), sopan santun (etiket yang menjunjung tinggi keberadaan hak azasi manusia secara universal dan bukan etiket dengan pengertian sempit/ lokal) dan tenggang-rasa (toleransi fisik dan rasa yang sudah melebur dalam tatanan sosiopsikologi dalam ukuran universal); perilaku 
erat hubungannya dengan wilayah teritorial kehidupan seseorang atau masyarakat tertentu, dalam kaitannya dengan kehidupan global akan memperluas batas teritorial dari skala lokal menuju ke skala internasional, berarti ada pemekaran batas teritorial

- pengaturan global pada dasarnya terlalu mengikatkan diri pada kebutuhan institusional yang sempit menuju pada perluasan kebutuhan institusional yang akan dapat menampung kepentingan masyarakat lingkungan internasional; kalaulah pengaturan ini berpijak pada halhal yang berhubungan dengan pengaruh, sikap dan perilaku seperti diuraikan sebelum ini, maka besaran institusi tidak perlu dipersoalkan lagi dan bahkan sifat kelembagaan yang terbatas pada dirinya sendiri telah ditinggalkan, beralih pada kepentingan semua pihak (internasional), seperti yang banyak dilakukan oleh masyarakat berbudaya Jawa.

Globalisasi sebagai satu kenyataan emperik, yang pada umumnya menyentuh beberapa kebutuhan konsumtif-ekonomis (using up of commodities or services, as opposed to their production) manusia meliputi pangan, sandang dan papan. Kehidupan nyata yang sebenarnya tidak berdiri atas ukuran pribadi tiap orang, melainkan satu orang dengan lainnya saling mempengaruhi, sehingga secara kuantitatif maupun kualitatif dan mengalami perubahan terus menerus, berkembang seiring dengan perkembangan jaman dan perjalanan waktu. Kedekatan terhadap sumber pengaruh berakibat besar dalam upaya melakukan perubahan kenyataan hidup, sehingga baik tuntutan kebutuhan maupun tantangan berasal dari lingkungan sekitarnya tetap dapat berkembang saling mempengaruhi untuk sampai pada kedudukan 'keseimbangan' yang relatif diharapkan oleh pihak yang bersangkutan.

Kepribadian sebagai bagian dari kebudayaan mengandung pola pikir berkepribadian, yang beranggapan bahwa budaya bukan merupakan bawaan sejak lahir namun suatu hal yang dapat dipelajari (Ronald,A., 1992), sehingga kehidupan budaya bukanlah suatu perujudan hidup yang statis dan mati. Selain itu, juga mengandung perbuatan yang berkepribadian, yang di dalamnya terdapat berbagai dimensi yaitu:
- mistis yang merasakan dirinya berada dalam kekuatan gaib; sebuah kekuatan yang lebih besar yang berpengaruh pada satu bagian atau keseluruhan kehidupan budaya seseorang

- ontologis yang ingin selalu mengetahui dan meneliti hal ikhwal berhubungan dengan kehidupannya baik langsung maupun secara tidak langsung; sebuah keinginan yang muncul dari benak orang karena dalam takdir yang diterimanya, telah diterimakan kemampuan untuk berfikir dan berkreasi

- fungsional yang berusaha mengadakan relasi-relasi baru suatu kaitan yang baru terhadap segala sesuatu dalam lingkungannya; sebuah kemampuan yang dimiliki orang sebagai makhluk yang hidup berkoloni baik itu dilakukan secara naluriah maupun atas dasar kemampuan menalarnya, yang kesemuanya itu ada dalam lingkup kebudayaan saling berhubungan satu dengan lainnya dan budaya yang terbentuk oleh tanggapan yang dipelajari atas situasi tertentu, yang berlangsung berulang-ulang secara konsekuen dan konsisten.

Kepribadian sebagai satu pengaruh pada umumnya menyangkut pemikiran berkepribadian yang selalu berusaha mengembangkan kehidupan diri mengikuti perkembangan jaman, sekalipun tidak melepaskan dari hakekat inti kehidupannya (Jawa: sejatining urip, sejatining laku). Kemudian, menyangkut perihal sikap berkepribadian yang membuka diri untuk bertoleransi besar terhadap pengaruh luar yang datang kemudian, mungkin sekali merubah berbagai tatanan yang ada sebelumnya. Lebih lanjut, menyangkut perilaku berkepribadian dalam bentuk gerak laku yang memberikan dukungan sepenuhnya pada sikap, dalam banyak hal akan membentuk tatanan hidup sejahtera baik lahir maupun batin sesuai dengan ketentuan sikapnya. Selebihnya, adalah menyangkut pengaturan berkepribadian yang pada dasarnya merupakan bentuk upaya nyata yang berkaitan erat dengan tatanan perilakunya, ini merupakan bentuk ungkapan nyata dari perilaku untuk dapat dimengerti oleh masyarakat luas yang berada di sekitarnya. 
Kehidupan budaya Jawa setelah melampaui masa kejayaan pada jaman kesultanan atau kasunanan Jawa pada masa yang lalu, tampak telah mengalami banyak perubahan terutama bagi mereka yang tetap tinggal di wilayah pulau Jawa khususnya di Jawa Tengah (Surakarta) dan Daerah Istimewa Yogyakarta (Yogyakarta). Wilayah ini pada masa yang lalu telah banyak dikenal sebagai sumber awal perkembangan kebudayaan Jawa, dengan sebutan Negari Gung (negari adalah negara atau kawasan dan gung berasal dari kata agung yang berarti besar atau dapat pula ditafsirkan seperti pusat). Untuk memahami berbagai perubahan itu, perlu berpijak pada sudut pandang tertentu, yang dari waktu ke waktu dapat bertindak sebagai faktor yang menentukan berbagai bentuk perubahan kehidupan budaya bersangkutan; faktor itu antara lain adalah geografi, kemasyarakatan (faham) dan kepribadian. Bertitik-tolak dari gambaran ini dapatlah dirumuskan beberapa masalah berikut ini, yaitu:

a) masyarakat Jawa semula tinggal di kawasan subur, di dataran rendah dan hidup sebagai masyarakat agraris, saat ini sebagian besar jumlah penduduk berada di perkotaan dengan potensi dan kondisi geografis yang sangat berbeda, sehingga rumah Jawa dengan ciri-ciri khasnya sudah sulit ditemukan lagi; bukankah kehidupan budaya tidak hanya bergantung pada ujud artefaktual semata?

b) sebagian terbesar masyarakat Jawa semula hidup berbudaya menganut faham "kejawen", pada saat ini bahkan keaslian suku Jawa telah tidak murni lagi mengingat keberadaan suku ini telah banyak bercampur kehidupan budaya dari suku bangsa pendatang yang lain dan sudah cukup lama tidak lagi menganut faham itu sekalipun pada umumnya mereka mengaku hidup berbudaya Jawa, sehingga rumah dengan kemurnian budaya Jawa sulit ditemukan lagi dalam arti kenyataan visualistik namun dalam percaturan internasional bukankah istilah Jawa (Java) telah berakar cukup kuat dan mendalam di berbagai percaturan? masyarakat Jawa semula menyatakan hidup di bawah naungan ketentuan adat, yang berarti pula menganut pola kepribadian Jawa, pada saat ini ciri-ciri kepribadian semacam itu telah menjadi kabur, sehingga rumah dengan ciri-ciri khas berkepribadian Jawa tampak sulit ditemukan di lapangan sekalipun tidak berpakaian Jawa bukankah dalam tataran berbahasa berlangsung terus baik secara verbal maupun non-verbal?

\section{ARSITEKTUR DALAM FORMAT BAHASA}

Arsitektur sebagai sebuah bentuk yang di dalamnya mengandung berita, sedangkan berita yang dimaksudkan di sini - seperti telah djelaskan sebelum ini adalah suatu bentuk ajaran moral, yang diharapkan dapat mendewasakan orang yaitu paling sedikit adalah penghuni rumah itu. Ajaran moral dalam hal ini ditujukan khususnya kepada keluarga yang tinggal di dalamnya atau lebih tepatnya dalam berarsitektur rumah Jawa, adalah keluarga yang tinggal di dalam rumah. Ajaran Jawa membedakan orang ke dalam empat status keluarga, yaitu keluarga inti, majemuk atau keluarga dekat, kerabat dekat dan kerabat jauh atau orang lain sama sekali. Di samping status keluarga, ajaran ini juga membedakan sasarannya yaitu orang dewasa dan anak-anak, sehingga sebegitu jauh bagi orang dewasa merupakan kewajiban, sedang bagi anak-anak masih harus belajar lebih dahulu dengan arahan dari panutannya yaitu orang - orang yang lebih tua atau yang seharusnya telah memiliki pengetahuan tentang hidup berbudaya sebagaimana diwariskan oleh generasi pendahulunya. Selain itu, ajaran moral ini membedakan kemasan dalam perujudan yang berskala sakral dan profan, yang memperlihatkan nilainilai spiritual dari sebuah berita, merupakan bagian utama yang selalu mewarnai setiap bentuk pemberitaan dalam kehidupan seharihari.

Dalam ajaran yang bertolak pada status keluarga, terdapat jarak perbedaan mencolok antara keluarga inti dan kerabat jauh atau orang lain sama sekali, yaitu bahwa keluarga inti lebih menekankan pada kebenaran, sedang kerabat jauh atau orang lain menekankan pada kebaikan; artinya di dalam pengertian kebenaran terdapat pula makna jujur atau tidak perlu menutupi kenyataan yang terjadi tidak perlu ada kerahasiaan; sementara di dalam kebaikan lebih mengutamakan upaya menyenangkan pihak lain, agar hubungan kemanusiaan itu dapat 
lebih dekat lagi atau bilamana mungkin berubah status menjadi kerabat dekat. Berkaitan dengan konsep itu, bilamana ditransformasikan ke dalam ungkapan arsitektur maka kebenaran atau kejujuran itu dapat ditafsirkan menjadi steril, sedang kebaikan dapat ditafsirkan menjadi bervariasi atau bermodifikasi; keduanya mempunyai kualitas magnit atau daya tarik yang membedakan sikap penyambutan, antara yang pasif dan pro-aktif.

Dalam hal ajaran yang ditujukan pada orang dewasa, bahwa orang dewasa itu harus bersikap lebih tenang daripada anak-anak, dengan pengertian bahwa kedewasaan ini ibaratnya bulir padi yang telah masak, akan menunjukkan sifat kinerja menunduk, tenang dan teduh, sedang anak muda lebih memperlihatkan sifat kinerja riang gembira, bergejolak dan berganti-ganti. Perbedaan sifat, itu akan memperlihatkan suasana batin pihak bersangkutan, sehingga ketenangan lebih tepat berada di bagian tengah dan kegembiraan berada di bagian tepi atau dekat dengan luar. Suasana batin ini dapat ditafsirkan dalam ungkapan arsitektur dengan istilah atmosfir, berarti ketenangan menjadi statik (stabil) dan kegembiraan menjadi dinamik (labil). Suasana statik mengajarkan orang agar tidak berbuat salah dalam kehidupan duniawi ini setidaknya ketika berada di bagian tengah dari tempat tinggal ini. Suasana dinamik mengajarkan orang untuk berani mencoba berkreasi - sekalipun tidak terlalu benar, namun orang yang berada di dalamnya memiliki kebebasan lebih besar atau tidak terlalu terikat oleh adat-kebiasaan yang berlaku pada saat itu.

Dalam hal ajaran yang berskala sakral dan profan, terdapat perbedaan di antara keduanya dalam hal kebutuhan manusia pada kehidupan akhirat di satu sisi dan duniawi di sisi yang lain. Ketika dia sedang membutuhkan suasana spiritual, maka dia sedang menempatkan dirinya dalam dunia beserta dengan semesta alamnya, yang berkekuatan jauh melebihi kekuatan dirinya sendiri dan sekitarnya, kemudian tergambarkan sebagai tempat dengan suasana hening, mencekam dan misterius. Ketika dia sedang membutuhkan realita, maka dia sedang menempatkan diri dalam dunia nyata yang serba terukur, terlihat dan teraba, yang mengandung kekuatan merasa lebih besar, berkuasa dan dapat berusaha mengendalikannya. Dunia nyata ini kemudian terujud sebagai tempat dengan suasana ramai, bersifat kebendaan dan berencana.

Suasana hening mengajarkan untuk berkontemplasi, juga berevaluasi terhadap kejadian yang lampau dan memandang kehidupan ini berada dalam genggaman tangan Tuhan Yang Maha Kuasa dan dengan suasana demikian, setidaknya berada pada suatu tempat yang dianggap paling suci bila dibandingkan dengan tempat-tempat yang lain; tempat ini secara faktual berbatas dengan luasan yang kecil, tetapi pada dasarnya dalam anggapan orang tempat ini seakan-akan tidak punya batas dan luas tiada terhingga. Suasana ramai mengajarkan orang untuk bersedia berinteraksi dengan lingkungan sekitarnya, yang dalam hal ini menyangkut dimensi sosial, alam dan keruangan; tempat ini secara faktual berbatas dengan luasan yang besar, tetapi pada dasarnya dalam anggapan orang tempat ini tidak pernah mencukupi - mengingat bahwa orang mempunyai sifat tidak pernah puas dengan hasil yang diperolehnya secara duniawi.

\section{PENUTUP}

Arsitektur sebagai alat komunikasi sebagaimana telah diungkapkan di bagian depan, bahwa karya manusia tidak dapat melepaskan diri dari kebutuhan dan kepentingan orang yang sedang berkarya atau setidak-tidaknya aspirasinya telah sampai; aspirasi dari yang membutuhkan dan berkepentingan dalam hal ini sempat dicurahkan kepada pihak lain - dengan metoda komunikasi, sehingga hasil karya itu sendiri akhirnya menjadi bagian yang tidak terpisahkan dari sistem komunikasi yang sedang berlangsung. Telah pula diungkapkan bahwa dalam kehidupan masyarakat Jawa dikenal pitutur (nasehat filsafati), sementara arsitektur sebagai bagian dari karya budaya di dalam sistem tampilannya juga mengandung pesan hidup berbudaya, menunjukkan bahwa arsitektur adalah sebuah alat komunikasi yang berlangsung secara tidak langsung; untuk dapat lebih mengenal isi pesan itu membutuhkan pengetahuan untuk dapat membedahnya, sehingga keseluruhan isi dari pesan itu terjabarkan dengan jelas dan runtut. 
Arsitektur sebagai sebuah bahasa sebagaimana pengertian bahasa umumnya, bahwa di dalamnya terdapat satu tatanan tertentu disebut dengan tata-bahasa dan juga seni berbahasa atau kesusasteraan; demikian halnya dengan karya khususnya arsitektur Jawa, telah dijelaskan bahwa dia mengandung berita di dalamnya, kemudian dia adalah alat untuk komunikasi, dengan demikian semua itu dapat ditafsirkan pula sebagai sebuah bentuk bahasa yaitu bahasa non-verbal. Dengan bertitik-tolak pada pengertian ini, maka arsitektur pada dasarnya adalah sarana yang tepat untuk berbahasa terutama dalam lingkup kehidupan berbudaya, sebab arsitektur pun mampu menyampaikan pesan budaya. Kalau arsitektur itu menyangkut bentukan Jawa, padahal dalam bahasa Jawa dikenal memiliki tingkatan berbahasa Jawa tinggi (krama inggil), menengah (krama madya) dan rendah atau kasar (ngoko), tentunya seiring dengan kenyataan itu berarti dalam arsitektur Jawa, seharusnya juga terdapat pembedaan tingkatan itu, dengan tujuan untuk menunjukkan bahwa budaya Jawa sangat menghormati pihak-pihak lain yang berada di sekitarnya, bukankah kehidupan semacam ini jauh lebih baik?

\section{DAFTAR PUSTAKA}

Afiff, F., 1994, Menuju Pemasaran Global, -

Geertz, C., 1960, The Religion of Java, The University of Chicago Press, London

Hadiwijono, H., 1967, Man in the Present_Javanese Mysticism, Bosch \& Keuning NV, Baarn

Hardjowirogo, 1984, Adat Istiadat Jawa, Patma, Bandung

Herusatoto, B., 1983, Simbolisme Dalam Budaya Jawa, PT Hanindita, Yogyakarta

Koentjaraningrat, 1980, Javanese Terms for God and Supernatural Being and the Idea of Power; in: Man, Meaning and History, Martinus Nijhof, The Hague

Koentjaraningrat, 1984, Kebudayaan Jawa, PN Balai Pustaka, Jakarta.

Minai, A.T., 1984, Architecture as Environmental Communication, Mouton Pub. Berlin

Mulder, N., 1973, Kepribadian Jawa dan Pembangunan Nasional, Gadjah Mada Univ. Press, Yogyakarta

Mulder, J.A.N., 1975, Mysticism and Daily Life in Contemporary Java, --, Amsterdam

Ronald, A., 1992, Aspecten van de Bouwcultuur van de Traditionele Javaanse Woning en zijn Architectonische Expressie - doktoral disertatie, T U Delft, Delft

Soekanto, S. dan Soleman, B.T., 1983, Hukum Adat Indonesia, Rajawali, Jakarta

Wessing, R., 1978, Cosmology and Social Behavior in West Javanese Settlement, Ohio University Centre for International Studies, Ohio 